\title{
The Effect of Sex and Slaughter Ages on the Chemical Composition, Physical and Sensory Qualities of Merawang Chicken
}

\author{
Edi Suryanto ${ }^{1, *}$, Jamhari Jamhari ${ }^{1}$, Rusman Rusman ${ }^{1}$, Nanung Danar Dono ${ }^{2}$, Endy \\ Triyannanto ${ }^{1}$, Rio Olympias Sujarwanta ${ }^{1}$, Mochammad Fahmi Habibi ${ }^{3}$, Yuli Dwi \\ Irma Suryani ${ }^{1}$, Amilia Nur Fadhila ${ }^{1}$, Gustya Amalia Rizqy ${ }^{1}$
}

\author{
${ }^{I}$ Department of Animal Products Technology, Faculty of Animal Science, Universitas Gadjah Mada, Yogyakarta, \\ 55281, Indonesia \\ ${ }^{2}$ Department of Animal Nutrition and Feed Science, Faculty of Animal Science, Universitas Gadjah Mada, Yogyakarta, \\ 55281, Indonesia \\ ${ }^{3}$ Department of Animal Production, Faculty of Animal Science, Universitas Gadjah Mada, Yogyakarta, 55281, \\ Indonesia \\ *Corresponding author. Email: edi_ugm@ugm.ac.id
}

\begin{abstract}
The purpose of the experiment is to evaluate the effect of sex and slaughter ages on the chemical composition, physical, and sensory qualities of Merawang chicken meat. The materials used in this research were 20 Merawang chickens aged 10 and 20 weeks, consisting of 10 male and 10 female chickens. The variables observed on the chemical compositions included moisture, protein, fat, ash, and carbohydrate contents, while physical quality observation included $\mathrm{pH}$ value, water holding capacity (WHC), cooking loss, tenderness, and meat color. The sensory quality included color, odor, texture, tenderness, and acceptability. The data obtained were analyzed statistically using the Nested test. The results of the experiment showed that sex and slaughter ages had a significant effect $(\mathrm{P}<0.05)$ on the chemical compositions (moisture, fat, carbohydrate, and ash contents), physical quality ( $\mathrm{pH}$, tenderness, color $\mathrm{L}^{*}$ and color $\mathrm{b}^{*}$ ) and sensory quality (odor and tenderness) of Merawang chicken meat. The result showed that sex and slaughter ages had no significant effect $(\mathrm{P}>0.05)$ on protein content, WHC, cooking loss, color $\mathrm{a}^{*}$, texture, and acceptability of Merawang chicken meat. This experiment concluded that sex and slaughter ages affected the chemical compositions, especially moisture, fat, carbohydrate, and ash content. Female Merawang chicken meat has higher fat content than male ones but has better tenderness than male Merawang chicken.
\end{abstract}

Keywords: Merawang chicken, Sex, Slaughter ages, Chemical composition, Physical and Sensory Qualities.

\section{INTRODUCTION}

Merawang chicken is a local chicken from Merawang Village, Merawang District, Bangka Belitung Province, Indonesia. This chicken is a genetic source and asset, as stated by SK Mentan No. 2846/Kpts./LB.4301812012. Makmur et al [1] stated that local chicken is Indonesian germplasm that has the potential to be developed because geographically, it is very supportive of the spread of the population in almost all rural areas in Indonesia.

Currently, the demand for local chicken is increased as reported by [2] from 284,987 in 2016 reached 292,329 tons in 2019. This demand increased due to its taste which is more prevalent among Indonesian consumers [3]. Studies on the Kedu Local chicken revealed that female chicken has higher fat content than male ones [4]. The effect of sex and slaughter ages on the local chicken also has been reported by [5] that affected the weight of carcass and parts of Merawang chicken. However, its effect on the chemical, physical and sensory qualities has not been well known yet. The objective of this experiment is to observe the effect of sex and slaughter ages on the chemical, physical and sensory qualities in Merawang chicken meat. 
Table 1. The chemical composition of Merawang chicken meat with different sex and slaughter ages

\begin{tabular}{|l|l|l|l|l|}
\hline \multirow{2}{*}{ Variables } & \multicolumn{4}{|c|}{ Age and Sex } \\
\cline { 2 - 5 } & 10 wekks & \multicolumn{3}{|c|}{20 weeks } \\
\cline { 2 - 5 } & Male & Female & Male & Female \\
\hline Moisture content & $74.07 \pm 0.63^{\mathrm{a}}$ & $72.69 \pm 1.62^{\mathrm{b}}$ & $75.67 \pm 0.50^{\mathrm{a}}$ & $70.28 \pm 2.14^{\mathrm{b}}$ \\
\hline Protein content $^{\mathrm{ns}}$ & $19.99 \pm 0.39$ & $20.07 \pm 0.39$ & $16.79 \pm 4.91$ & $19.31 \pm 1.93$ \\
\hline Fat content & $3.57 \pm 1.04^{\mathrm{a}}$ & $4.08 \pm 1.82^{\mathrm{b}}$ & $2.21 \pm 0.91^{\mathrm{a}}$ & $6.73 \pm 2.84^{\mathrm{b}}$ \\
\hline Carbohydrate content & $0.40 \pm 0.28^{\mathrm{c}}$ & $1.47 \pm 0.58^{\mathrm{c}}$ & $4.90 \pm 4.65^{\mathrm{d}}$ & $2.62 \pm 2.04^{\mathrm{d}}$ \\
\hline Ash content & $1.71 \pm 0.04^{\mathrm{c}}$ & $1.70 \pm 1.13^{\mathrm{c}}$ & $1.37 \pm 0.22^{\mathrm{d}}$ & $1.43 \pm 0.10^{\mathrm{d}}$ \\
\hline
\end{tabular}

All values expressed as mean \pm standard deviation for physical quality.

a,b,c,d mean with different superscript letters in the same row differ significantly $(\mathrm{P}<0.05)$

\section{MATERIALS AND METHODS}

\subsection{Materials}

The materials used in this experiment were male and female Merawang chicken with ages of 10 and 20 weeks, buffer $\mathrm{pH} 4$ and 7, aquadest, polyethylene plastic, Sulfuric acid, $\mathrm{NaOH}-\mathrm{Na} 2 \mathrm{~S} 2 \mathrm{O} 3$ solution, boric acid $40 \%$, composite indicator methyl red-methyl blue or methylbromine, petroleum ether, asbestos ignited, anti-foaming agent, $\mathrm{H} 2 \mathrm{SO} 4$ solution, $\mathrm{NaOH}$ solution, $10 \% \mathrm{~K} 2 \mathrm{SO} 4$ solution, and $95 \%$ alcohol. While the equipment used in this experiment were glass beaker, stirrer, knife, cutting board, water bath, tissues, filter paper, glass plate, barbell $35 \mathrm{~kg}$, mica plastic, millimeters block, whiteboard marker, stopwatch, calipers, cylinder, clamp pliers, $\mathrm{pH}$ meters "Hanna" HI 98107, electric scale "Ohaus," vacuum machine "Powerpack" DZ300N model, oven "Memmert" UN55 model, warner-bratzler, CR 400 chromameter, grinder, desiccator, porcelain crucible, muffle furnace, electric stoves, Kjeldahl Flask, smoke room, Kjeldahl micro distillatory, Soxhlet, Erlenmeyer, litmus paper, spatula, sensory plate, and questioner paper.

\subsection{Methods}

Merawang chickens were slaughtered according to the Halal method. The carcasses were cut into several parts such as breast, leg, wings, and back. Chemical composition and color of meat were carried out by sampling Merawang chicken meat parts such as breast, leg, wings, and back consisted of 3 males and 3 females. The physical ( $\mathrm{pH}$, tenderness, cooking loss, and water holding capacity of meat) and sensory qualities, the breast was used of each age were 10 consisted of 5 males and 5 females. Physical and sensory qualities observation were conducted at the Laboratory of Meat Science and Technology, Faculty of Animal Science, Universitas Gadjah Mada (UGM), Yogyakarta. Chemical composition and physical quality were determined at the Laboratory of Food Technology and Agricultural Products, Faculty of Agricultural Technology, UGM, Yogyakarta.
The chemical composition (moisture, protein, fat, and ash contents) analyses were carried out according to the [6], while fat content analysis was obtained using the Soxhlet method [7]. Analyze of carbohydrate content analysis was quantified by acid-base hydrolysis (Yenrina, 2015). The physical analysis ( $\mathrm{pH}$, cooking loss, and tenderness) was performed based on [8] while Water Holding Capacity (WHC) analysis was carried out according to the [9]. Meat color was measured using a Konica Minolta chromameter (type CR400) calibrated with a standard color close to the meat's color measured by the CIE LAB method [10]. Sensory analysis was assessed with samples of Merawang chicken breast consisting of color, odor, texture, tenderness, and acceptability of the meat, which were tested subjectively by 15 untrained panelists using a questionnaire. The questionnaire contains scores for each parameter using a 5-point hedonic scale, where 5 is 'like very 'much', 4 is 'like', 3 is 'like moderately', 2 is 'dislike', and 1 is 'dislike very much'

\subsection{Data Analysis}

The experiment was carried out with two treatments, each with three replications for chemical composition and color and five replications for physical $(\mathrm{pH}$, tenderness, cooking loss, and water holding capacity of meat). Chemical composition, physical and sensory qualities were analyzed statistically using Nested by SPSS program version 25 [11].

\section{RESULTS AND DISCUSSION}

\subsection{Chemical Composition of Merawang Chicken Meats}

The chemical composition of Merawang chicken meat with different sex and slaughter ages is presented in Table 1. The result showed that sex affected the moisture content of Merawang chicken meat indicated by the value $(\mathrm{P}<0.05)$ while slaughter ages did not influence its moisture content. It could be because of the higher fat content on the female chicken compared to male ones. 
Table 2. The physical quality of Merawang chicken meat with different sex and slaughter ages

\begin{tabular}{|c|l|l|l|l|}
\hline \multirow{2}{*}{ Variables } & \multicolumn{4}{|c|}{ Age and Sex } \\
\cline { 2 - 5 } & 10 wekks & Female & Male & Female \\
\cline { 2 - 5 } & Male & $5.76 \pm 0.76^{\mathrm{b}}$ & $6.16 \pm 0.05^{\mathrm{c}}$ & $6.11 \pm 1.28^{\mathrm{d}}$ \\
\hline $\mathrm{pH}$ & $5.94 \pm 0.21^{\mathrm{a}}$ & $1.45 \pm 1.03^{\mathrm{b}}$ & $2.47 \pm 0.31^{\mathrm{c}}$ & $2.33 \pm 0.24^{\mathrm{d}}$ \\
\hline Tenderness $\left(\mathrm{kg} / \mathrm{cm}^{2}\right)$ & $2.55 \pm 0.14^{\mathrm{a}}$ & $14.65 \pm 10.23$ & $20.11 \pm 2.16$ & $14.51 \pm 10.18$ \\
\hline${\text { Cooking loss }(\%)^{\mathrm{ns}}}^{*}$ & $18.32 \pm 2.98$ & $42.65 \pm 6.26$ & $43.92 \pm 5.65$ & $36.88 \pm 7.20$ \\
\hline WHC (\%)ns & $44.52 \pm 10.39$ & & & \\
\hline Color & & $41.56 \pm 0.24^{\mathrm{b}}$ & $53.57 \pm 1.53^{\mathrm{c}}$ & $46.79 \pm 0.16^{\mathrm{d}}$ \\
\hline $\mathrm{L}^{*}$ & $41.45 \pm 0.22^{\mathrm{a}}$ & $2.47 \pm 0.52^{\mathrm{b}}$ & $2.86 \pm 1.54^{\mathrm{a}}$ & $1.59 \pm 0.18^{\mathrm{b}}$ \\
\hline $\mathrm{a}^{*}$ & $1.44 \pm 0.09^{\mathrm{a}}$ & $10.58 \pm 0.16^{\mathrm{b}}$ & $5.72 \pm 0.26^{\mathrm{c}}$ & $4.42 \pm 1.21^{\mathrm{d}}$ \\
\hline $\mathrm{b}^{*}$ & $8.29 \pm 0.33^{\mathrm{a}}$ & & \\
\hline
\end{tabular}

All values expressed as mean \pm standard deviation for physical quality.

a,b,c,d mean with different superscript letters in the same row differ significantly $(\mathrm{P}<0.05)$

Winarso [12] stated that if the fat content in meat is high, the moisture content in the carcass is lower. Following the study result, the percentage of moisture content of male Merawang chicken meat was higher than female Merawang chicken. Comparing these results (70.28 to $75.67 \%$ ) with those of [13], the moisture content of local chicken meat was around $63.22 \%$. However, these values are still within the normal range of meat moisture content reported by [14] that the moisture content range of chicken meat is between 65 to $80 \%$.

The result of protein content showed that sex and slaughter ages did not affect the protein content of Merawang chicken meat indicated by the value $(\mathrm{P}>0.05)$. The protein contents of this Merawang chicken (16.79 to $20.07 \%$ ) are within the normal range as stated by [14] that the protein content range of chicken meat is 16 to $22 \%$. The protein content of meat chicken 20 old weeks was lower than meat from 10 old weeks chicken. Sudrajat and Setiyono [15] stated that the older chicken, the meat protein level decreased. The result showed that sex affected the fat content of Merawang chicken meat indicated by the value $(\mathrm{P}<0.05)$, while slaughter ages did not influence its fat content. The fat content of female Merawang chicken meat (4.08 to $6.73 \%$ ) was higher than male Merawang chicken meat (2.21 to $3.57 \%$ ). Novele et al. [16] stated that female chicken deposits more body fat than male chicken. The values are still within the normal range of meat fat content, as [17] reported that the fat content range of chicken meat is 1.2 to $12 \%$.

The experiment result showed that slaughter ages affected the carbohydrate content of Merawang chicken meat indicated by the value $(\mathrm{P}<0.05)$, while sex did not influence the carbohydrate content. This meat carbohydrate content ( 0.40 to $4.90 \%$ ) was higher than the study reported by [18] stated that the carbohydrate content of meat is 0.5 to $1.0 \%$. The ash content and slaughter ages affected Merawang chicken meat's ash content indicated by the value $(\mathrm{P}<0.05)$, while sex did not influence the ash content. These meat ash contents $(1.37$ to $1.71 \%$ ) are higher than the study reported by [19], which stated that the ash content of local chicken meat is $1.0 \%$. Liur and Tagueha [20] stated that the ash content would increase as chicken age increased. Therefore, it can be argued that twenty weeks old Merawang chicken has a lower ash count than 10 weeks old Merawang chicken due to increased meat moisture content.

Table 3. The sensory quality of Merawang chicken meat with different sex and slaughter ages

\begin{tabular}{|l|l|l|l|l|}
\hline \multirow{2}{*}{ Variables } & \multicolumn{4}{|c|}{ Age and Sex } \\
\cline { 2 - 5 } & \multicolumn{3}{|c|}{10 wekks } & \multicolumn{2}{c|}{20 weeks } \\
\cline { 2 - 5 } & Male & Female & Male & Female \\
\hline Color $^{\text {ns }}$ & $3.59 \pm 0.32$ & $3.38 \pm 0.12$ & $3.45 \pm 0.19$ & $3.35 \pm 1.17$ \\
\hline Odor & $3.51 \pm 0.07^{\mathrm{a}}$ & $3.37 \pm 0.07^{\mathrm{a}}$ & $3.19 \pm 0.15^{\mathrm{b}}$ & $3.28 \pm 0.13^{\mathrm{b}}$ \\
\hline Texture $^{\text {ns }}$ & $3.41 \pm 0.19$ & $3.54 \pm 0.18$ & $3.38 \pm 0.14$ & $3.27 \pm 0.22$ \\
\hline Tenderness $^{*}$ & $3.63 \pm 0.12^{\mathrm{a}}$ & $3.50 \pm 0.14^{\mathrm{a}}$ & $3.48 \pm 0.14^{\mathrm{b}}$ & $3.21 \pm 0.29^{\mathrm{b}}$ \\
\hline Acceptability $^{\text {ns }}$ & $3.54 \pm 0.19$ & $3.60 \pm 0.21$ & $3.55 \pm 0.14$ & $3.52 \pm 0.18$ \\
\hline
\end{tabular}

All values expressed as mean \pm standard deviation for physical quality.

$\mathrm{a}, \mathrm{b}, \mathrm{c}, \mathrm{d}$ mean with different superscript letters in the same row differ significantly $(\mathrm{P}<0.05)$

$$
\text { .. . ... }
$$




\subsection{The Physical Quality of Merawang Chicken Meat}

The physical quality of Merawang chicken meat with different sex and slaughter ages is presented in Table 2 . The result of physical quality showed that sex and slaughter ages affected the $\mathrm{pH}$ of Merawang chicken meat $(\mathrm{P}<0.05)$. The $\mathrm{pH}$ values of the age of 20 weeks (6.11 to 6.16) are higher than the age of 10 weeks (5.76 to 5.94). Following [21], the $\mathrm{pH}$ value of the meat ranged between 5.82 to 6.79. [8] stated that the $\mathrm{pH}$ of the meat is associated with tenderness, where the meat with high $\mathrm{pH}$ has a high tenderness compared with low $\mathrm{pH}$. Meat with a $\mathrm{pH}$ above (6.0) contains juice, which causes the meat to be more tender. Sex influences the $\mathrm{pH}$ of the meat [22]. The genotype of the chicken and the structure of the muscles on the chicken cause a difference in the $\mathrm{pH}$ value of the meat chickens. In contrast, the result of tenderness showed that sex and slaughter ages affected the tenderness of Merawang chicken meat $(\mathrm{P}<0.05)$. Purnamasari et al. [23] stated that the age of the relatively slaughter ages cause tenderness of the meat is low and less liked by the panelists.

This experiment showed that sex and slaughter ages did not affect the cooking loss of Merawang chicken meat $(\mathrm{P}>0.05)$. Soeparno [8] stated that meat cooking loss generally ranges from 1.5 to $54.5 \%$. While for WHC, the result showed that sex and slaughter ages did not affect the WHC of Merawang chicken meat $(\mathrm{P}>0.05)$. Purnamasari et al. [23] stated that the factors affecting WHC are age, breed, feed, temperature and humidity, $\mathrm{pH}$, the formation of actomyosin (rigor mortise), the type of meat, and the location of the muscle, muscle function, and intramuscular fat.

\subsection{Sensory Quality of Merawang Chicken Meat}

The sensory quality of Merawang chicken meat with different sex and slaughter ages is presented in Table 4. The result showed that sex and slaughter ages affected the odor and tenderness of Merawang chicken meat $(\mathrm{P}<0.05)$. In comparison, sex and slaughter ages did not affect the color, texture, and acceptability of Merawang chicken meat $(\mathrm{P}>0.05)$. Soeparno [8] stated that an important sensory quality element for meat is the appearance of meat color as it is the first sensory that panelists can see. The fat content and age of the slaughtered chickens, according to [24], influence the odor of chicken meat. According to [25], the food industry relies on odor observation to quickly determine acceptable products. According to [26], the texture is linked to a sense of touch, crucial in forming meat quality. While for tenderness, [27] stated that changes in the collagen molecule will affect chicken meat's tenderness as ages increase. The result showed that sex and slaughter ages did not affect the acceptability of Merawang chicken meat (3.52 to 3.60 as 'like moderately' to 'like'). Soeparno [8] stated that the value of meat is based on the acceptability of consumers. It is based on the satisfaction from meat consumers depending on physiological and sensory responses among individuals.

\section{CONCLUSION}

This experiment concluded that sex and slaughter ages affected the chemical compositions, especially moisture, fat, carbohydrate, and ash content. Female Merawang chicken meat has higher fat content compared to male ones. Females Merawang chicken meat has better tenderness than male Merawang chicken.

\section{AUTHORS’ CONTRIBUTIONS}

Conceptualisation ES. and ROS; methodology ANF, GAR, and YDIS, software ROS, validation E. S., formal analysis E. S and ROS, investigation ES and ROS, resources E. S. and ROS, writing-original draft preparation ES, R. O. S., ANF, GAR, and Y. D. I. S., writing review and editing E. S., and ROS, visualization ES and ROS, supervision ES and ROS, project administration ES All authors have read and agreed to the published version of the manuscript.

\section{ACKNOWLEDGMENTS}

We want to take this opportunity and be thankful for our team projects and all participants who have helped and participated in this project from the Faculty of Animal Science, Gadjah Mada University.

\section{REFERENCES}

[1] Makmur, A., Sugito, and Samadi. 2018. The effect of giving various types of feed additives on the moisture and protein content of Super Kampong Chicken meat (Gallus domesticus). Proceedings of the National Biotic Seminar. 557-562.

[2] Solikhatin, E., A. Fanani, and M. S. Husein. 2018 Local chicken agribusiness development strategy in Tuban District East Jave Province. Research Innovation Journal. 2(2): 63-70.

[3] Statistics Indonesia. 2019. Broiler Meat Production by Province, 2009 to 2019. Jakarta: Statistics Indonesia.

[4] Suryanto, E. Jamhari, Rusman, N. D. Dono, E. Triyananto, R. O. Sujarwanta, M. F. Habibi, F. Antami, and N. S. P. Azzahra. 2020. Chemical, physical, and sensory qualities of male and females Kedu chicken meat. Journal Simnaster. (in press).

[5] Suryanto, E. Jamhari, Rusman, N. D. Dono, E. Triyannanto, R. O. Sujarwanto, M. F. Habibi, and R. Aljiansyah. 2021. The effect of sex and 
slaughter ages on the weight, percentage, and parts of a carcass of merawang chicken. 2nd ICAPFS. (in press).

[6] AOAC. 1970. Official Method of Analysis of the Association of Official Analytical Chemists. Benyamin Franklin Station, Washington, DC.

[7] Sudarmadji. S., B. Haryono, and Suhardi. 1981. Analytical Procedures for Foodstuffs and Agriculture. Liberty, Yogyakarta.

[8] Soeparno. 2015. Meat Science and Technology. Sixth Printing (Revised Edition). Gadjah Mada University Press, Yogyakarta.

[9] Hamm, R. 1972. Kolloidchemie des Fleischesdes Wasserbindungs-vermoegen des Muskeleiweisses in Theorie und Praxis.Verlag Paul Parey, Berlin.

[10] Sinaga, A. S. 2019. L*a*b* Color Space Segmentation. Penusa Mantik Journal. 3(1): 4346.

[11] Steel, R. G. D. and J. H. Torrie. 1980. Principles and procedures of statistics a biometrical approach. McGraw-Hill International Book Company.

[12] Winarso, D. 2003. Changes in physical characteristics due to differences in age, muscle type, time, and temperature of boiling chicken meat. Indonesian Journal of Tropical Animal Agriculture. 28(3):119-132.

[13] Hidayah, R., I. Ambarsari, and Subiharta. 2019. Study of nutritional physical and sensory quality of KUB chicken meat in Central Java. Indonesian Animal Husbandry Journal.21 (2): 93-101.

[14] Soeparno. 2011. Meat Nutrition and Nutrition Science. Gadjah Mada University Press, Yogyakarta.

[15] Sudrajat, D. and Setiyono. 2017. The use of different ratio protein levels on the performance of laying males. Agricultural Journal. 6(2):68-74.

[16] Novele, D. J., J. W. Ng'ambi, D. Norris, and C. A. Mbajiorgu. 2008. Effect of sex, level and period of feed restriction during the starter stage on productivity and carcass characteristics of ross 308 broiler chickens in south africa. Int. J. Poult. Sci. 6: 530-537.

[17] Dewi, S. H. C. 2013. Chemical quality of chicken meat with broiler concentrate based rations. Agriscience Journal. 4(6):42-50.

[18] Rukmini, N. K. S., N. K. Mardewi, and I. G. A. D. S. Rejeki. 2019. Chemical quality of 5 week old broiler chicken reared in different cage densities.
Journal of Environtent and Development. 3(1): 31-37.

[19] Fauzi, M. 2006. Analysis of Food and Agricultural Product. Jember. FTP UNEJ.

[20] Liur, I. J. and A. D. Tagueha. 2020. Chemical quality and microorganism of broiler chicken meat at the modern market in Ambon City. Journal of Food Science and Technology. 5(6):3506-3515.

[21] H. Koesmara., I.G.S. Budisatria., E. Baliarti., T.S.M. Widi., A. Ibrahim., B.A. Atmoko amd Vierman. Effect of feeding different forage and concentrate levels on carcass characteristics and meat quality of Aceh Cattle. IOP Conf. Series: Earth and Environmental Science Vol 387, 2019, Pp 1-4. https://doi:10.1088/17551315/387/1/012080.

[22] Firdaus, M. 2019. Physicochemical and Organoleptic Characteristics of Aceh Beef and Brahman Cross Cattle during Storage at $40 \mathrm{oC}$. Thesis. Animal Science. Universitas Sumatera Utara.

[23] Purnamasari, E., M. Zulfahmi, and I. Mirdhayati. 2012. Physical properties of rejected laying hens soaked in pineapple peel extract (Ananas comosus L. Merr) with different concentrations. Journal Livestock. 9(1): 1-8.

[24] Manafe, M. E. and M. L. Ressie. 2021. Organoleptic broiler chicken through the use of purslane flour (Portulaca oleracea L) which substituted in commercial rations. Indonesian Journal of Animal Science. 16(1):68-74.

[25] Kartika, B. 1988. Food Sensory Test Guidelines. PAU Food and Nutrition. Universitas Gajah Mada, Yogyakarta.

[26] Komariah, S. and D. Purnomo 2005. Various of Processed Beef. Agroedia Library. Jakarta.

[27] Berri, C. 2004. Poultry Meat Processing and Quality. Woodhead Publishing. Pages 21-37. 